\title{
Phylogenetically mediated anti-predator responses in bivalve molluscs
}

\author{
Sascha M. M. Fässler ${ }^{1, *}$, Michel J. Kaiser ${ }^{2}$ \\ ${ }^{1}$ Gatty Marine Laboratory, University of St. Andrews, St. Andrews, Fife KY16 8LB, UK \\ ${ }^{2}$ School of Ocean Sciences, Bangor University, Menai Bridge, Anglesey LL59 5AB, UK
}

\begin{abstract}
Sedentary, group-living taxa, such as bivalves, respond to waterborne predator cues by enhancing tissues that increase anti-predation attributes such as muscle and shell mass. The ability of bivalves to differentiate among cues generated by the consumption of different prey species that vary in phylogenetic relatedness is unknown. We exposed mussels to cues generated by crabs feeding on mussels, cockles and periwinkles to test whether there was a relationship between the magnitude of the induced response and the level of relatedness to the cue source. Mussels exposed to either effluents of unfed crabs or seawater only served as controls. Exposure to cues from conspecifics and cockles caused significantly reduced growth in shell size of mussels compared to control mussels. Shell growth of mussels exposed to cues from crabs feeding on periwinkles did not differ significantly from mussels exposed to effluents from unfed crabs only. Tissue dry weight increased least in mussels exposed to cues of crabs fed conspecifics, followed by mussels exposed to crabs fed cockles. Cues of crabs that were fed mussels caused increased byssus thread production, whereas the other treatments did not. Exposure to cues from crabs fed mussels and crabs fed cockles resulted in significantly thicker and heavier shells compared to unexposed control mussels. The results of this study indicate that alarm cues of progressively more closely related molluscs cause a higher degree of induced morphological anti-predator responses in mussels. The physiological and behavioural responses of mussels to these cues may therefore have a phylogenetic basis.
\end{abstract}

KEY WORDS: Alarm cues · Heterospecifics · Inducible defences · Mytilus edulis · Phylogenetic relationship

Resale or republication not permitted without written consent of the publisher

\section{INTRODUCTION}

Mussels (Bivalvia: Mytilidae) are prominent organisms that are often the dominant species in terms of biomass. They form a key component of many marine communities (Seed 1976) and are an important link in the transfer of energy, in the form of phytoplankton or detritus, from the pelagic to the benthic system (Asmus \& Asmus 1993). Mussels are also commercially important throughout the world (Hickman 1992) and are cultivated on ropes or in artificially created mussel beds (Beadman et al. 2003). Both natural and commercial mussel beds are predated by a wide variety of predators including decapod crustaceans (Ebling et al. 1964), gastropods (Seed 1969), starfishes (Norberg \& Tedengren 1995), shorebirds (Goss-Custard \& Durrell 1987), fishes (Dare 1976) and mammals (Seed 1993).
Cultivated and naturally seeded mussels lose a significant part of their production to such predators (Seed \& Suchanek 1992). For example, Caldow et al. (2003) estimated that oystercatchers could remove nearly $50 \%$ of the biomass of a commercially cultivated mussel bed under certain circumstances.

Group living confers a number of anti-predation advantages in relatively sessile biota such as mussels. In addition, mussels are able to adapt phenotypically in response to predation threats. As in other invertebrate organisms such as protozoans (Wicklow 1988), bryozoans (Harvell 1984), cnidarians (Grosberg 1988), barnacles (Lively 1986) and gastropods (Appleton \& Palmer 1988), mussels are able to react to waterborne cues of their predators or cues of damaged conspecifics by inducing morphological changes that have an antipredation function (Côté 1995, Reimer \& Tedengren 
1996, Leonard et al. 1999, Smith \& Jennings 2000, Reimer \& Harms-Ringdahl 2001, Freeman \& Byers 2006). Furthermore, these responses are specific in character since attack modes vary considerably between predators. Leonard et al. (1999) reported that mussels produced thicker shells when exposed to cues from crabs Carcinus maenas and to cues from damaged conspecifics. Smith \& Jennings (2000) observed the same response when they exposed mussels to effluents from whelks Nucella lapillus and crabs. Thickening the shell provides effective protection against drilling and crushing predators, but is less effective against predators that use different predation strategies. Starfishes, for example, pull the shell valves apart using their tube feet and insert their stomach through the resulting aperture (Norberg \& Tedengren 1995). Accordingly, mussels exposed to cues from starfish Asterias rubens were found to increase the mass of their adductor muscles to resist higher pulling forces (Reimer \& Tedengren 1996, Reimer \& HarmsRingdahl 2001). Other responses to predator cues are enhanced byssus thread production (Côté 1995, Leonard et al. 1999, Reimer \& Harms-Ringdahl 2001) and clumping behaviour (Côté \& Jelnikar 1999). The use of these anti-predator defences significantly diminishes predator attack success and therefore directly increases survival and, ultimately, fitness (Leonard et al. 1999, Smith \& Jennings 2000, Reimer \& Harms-Ringdahl 2001). In the case of Mytilus edulis, which faces high, variable and unpredictable predation pressure, permanent defences would incur fitness costs that could be avoided when predators are absent (Tollrian \& Harvell 1999).

Despite the advances in describing magnitudes and causes of predator-inducible morphological defence responses in Mytilus edulis, little is known about the origin and composition of the olfactory cues involved (but see Griffiths \& Richardson 2006). Numerous studies have indicated that a wide variety of fishes not only show predator avoidance behaviour when exposed to alarm cues (i.e. 'Schreckstoff') of damaged conspecifics, but also to those of more distantly related heterospecifics (Mathis \& Smith 1993, Wisenden et al. 1995, Brown \& Godin 1997, Mirza \& Chivers 2003). Based on the same principle, dead conspecifics often act as a deterrent to baited trap entry by epibenthic scavengers (Moore \& Howarth 1996).

To date, it appears that cues released from conspecifics evoke much stronger responses than cues released by distantly related species. An investigation of the response of a prey species to cues released from species of a sequentially decreasing phylogenetic relatedness might elucidate whether there is a phylogenetic basis for the response exhibited by the prey. In the present study we examined to what extent efflu- ents of different molluscs of differing taxonomic relatedness elicited defence responses in the blue mussel Mytilus edulis. We measured the magnitude of the change in shell morphology and the allocation of energy to tissue growth and byssal production for mussels exposed to the effluents of different molluscs.

\section{MATERIALS AND METHODS}

To test the morphological responses of mussels to effluents from heterospecific molluscs with different levels of relatedness, juvenile mussels Mytilus edulis (shell length 9.2 to $16.7 \mathrm{~mm}$ ) were exposed to waterborne olfactory cues from crabs Carcinus maenas feeding on either conspecific mussels (bivalve), cockles Cerastoderma edule (bivalve) or periwinkles Littorina littorea (gastropod). Mussels were collected from rocks on the north side of Llanddwyn Island (Anglesey, UK) $3 \mathrm{~d}$ before the start of the experiment. Crabs (carapace width 44.9 to $69.5 \mathrm{~mm}$ ) and periwinkles were collected from the Menai Strait (Anglesey, UK), and cockles from Traeth Abermenai (Anglesey, UK). After collection, all specimens were maintained in flowing seawater at ambient temperature. Prior to experimental treatment, mussels were numbered individually with white paint marker, and the paint sealed with a drop of cyanoacrylate glue (Loctite ${ }^{\mathrm{TM}}$ ). Initial maximum shell dimensions (length, height and width) were measured to the nearest $0.1 \mathrm{~mm}$ for every mussel. Individual total wet weights (shell + tissue wet weights, $\pm 0.001 \mathrm{~g}$ ) were obtained after having blotted the mussels with paper towels. Prior to the start of the laboratory experiment, 50 mussels were selected from across the entire size spectrum of the collected mussel sample (8.4 to $20.2 \mathrm{~mm}$ ). These mussels were dissected, their shells and tissue separated and dried in an oven for $22 \mathrm{~h}$ at $90^{\circ} \mathrm{C}$ to obtain an initial wet to dry weight relationship. The remaining mussels $(n=200)$ were used for the experimental procedures.

Inducible morphological changes. At the start of the experiment, 10 mussels were randomly assigned to each of twenty $5 \mathrm{l}$ plastic tanks, and the tanks in turn were assigned randomly to one of 5 treatments $(n=4$ replicate tanks per treatment). The different treatment waters were prepared for $15 \mathrm{~h}$ overnight, 4 times a week, and consisted of effluents of either (1) crabs feeding on conspecific mussels, (2) crabs feeding on cockles, (3) crabs feeding on periwinkles, (4) unfed crabs only, or (5) unaltered seawater, which served as a control. We term these treatments: mussel, cockle, periwinkle, crab and control, respectively. For treatment water preparation, crabs were allocated randomly to four of five 151 plastic tanks $(n=4$ crabs per tank), each of which was filled with unaltered sea- 
water from the Menai Strait. There was no exchange of water over the preparation period during which the water was aerated. For the 'crab + prey' treatments, crabs were then fed the respective prey organisms, equivalent to the weight of 3 adult mussels to control for the effect of prey biomass.

Tanks with experimental mussels were supplied with flowing water at ambient temperature from the Menai Strait. Four times a week, the water supply to these tanks was stopped and the appropriate 'treatment water' added to each replicate tank and then left in a static condition for $8 \mathrm{~h}$ with aeration, after which flowing water was restored. During the course of the experiment, mussels were fed a high concentration mixture of algae (>2000 cells $\mu^{-1}$ ) consisting of $R$ hinomonas reticulata, Pavlova lutheri and Tetraselmis chuii cells. At the start of each exposure period during the day, $2 \mathrm{dl}$ of algal mixture was added to each of the individual 51 tanks holding the experimental mussels. A further $2 \mathrm{dl}$ of algae was added to each tank at night.

Crab and mussel feeding was monitored visually every day before and after the exposure period, respectively. Shells and any larger remains of consumed prey organisms were removed by filters before treatment waters were poured into the tanks containing experimental mussels. Water flow rates and water temperature were checked on 4 days per week. At the beginning of each week during the experiment, all experimental mussels were measured (maximum shell dimensions) and weighed (total wet weight). After $48 \mathrm{~d}$, the experiment was stopped and all experimental mussels were measured for final shell length, shell height, shell width and total wet weight. For each individual mussel, the shell, posterior adductor muscle and remaining tissue were separated, dried to a constant weight at $90^{\circ} \mathrm{C}$ for $72 \mathrm{~h}$, and weighed $( \pm 0.0001 \mathrm{~g})$ to determine biomass allocation and shell growth. Initial dry tissue to total wet weight ratio was determined by fitting a linear relationship to the data from the field population sample collected at the start of the experiment $\left(\mathrm{r}^{2}=0.916, \mathrm{n}=50, \mathrm{p}<0.001\right)$ :

$$
W_{f \text { dry }}=0.054 \times W_{\text {m wet }}-0.0036
$$

where $W_{f}$ and $W_{\mathrm{m}}$ represent weight of the flesh and of the whole mussel, respectively. Using the same principle as for determining initial dry tissue weight, initial shell to total wet weight was determined using the data of the initial mussel sample from the field population $\left(\mathrm{r}^{2}=0.965, \mathrm{n}=50, \mathrm{p}<0.001\right)$ :

$$
W_{\mathrm{sdry}}=0.5148 \times W_{\mathrm{m} \text { wet }}-0.0082
$$

where $W_{\mathrm{s}}$ and $W_{\mathrm{m}}$ describe the weight of the shell and of the whole mussel, respectively. The shell surface area $(A)$ was approximated using Eq. (3). This formula describes an ellipsoid-like shape and should give esti- mates relatively close to the true surface area (Reimer \& Tedengren 1996):

$$
A=I \sqrt{\left(h^{2}+w^{2}\right)} \times \frac{1}{2} \pi
$$

where $l$ is the shell length, $h$ the shell height and $w$ the shell width. An index of shell thickness was calculated by dividing shell weight by the surface area of the shell.

Byssus thread production. The effect of treatment waters on byssus thread production was investigated in the laboratory $40 \mathrm{~d}$ into the experiment. Experimental mussels were detached carefully from the walls of the experimental tanks and all remaining threads were cut as close as possible to the shell valves. The same replicate groups of mussels were placed into $1 \mathrm{dl}$ Petri dishes ( $\mathrm{n}=10$ mussels per dish) and respective treatment waters were poured into the Petri dishes, which were then covered. While immersed in their respective treatment waters, the mussels were allowed to attach for $6 \mathrm{~h}$. The number of threads produced by each mussel was counted through the Petri dish under a dissecting microscope at the end of the attachment period. Afterwards, all mussels were dislodged and placed back into their respective 51 tanks.

Statistical analysis. To analyse the effects of predator, conspecific and heterospecific effluent on mussel morphology, biomass allocation, growth and byssus production, morphological features were compared between the different treatments using a 2-factor nested ANOVA. The 2 factors were 'treatment' and 'tanks within treatment' (random factor), with the latter nested within the former. Morphological attributes and count data were $\log _{10}(x+1)$ transformed prior to analysis. Likewise, proportion data were $\operatorname{arcsine}(\sqrt{x})$ transformed. All data were tested for normal distributions (Anderson Darling test) and homogeneity of variances (Bartlett's test). If assumptions of normality did not hold, a non-parametric Kruskal-Wallis test was used and treatment effects were tested using Dunn's procedure for all pairwise comparisons between treatment medians. Where initial differences in size were found between treatments, effects of initial dimensions on the increment in respective sizes were tested among treatments using ANCOVA. If a significant treatment effect was detected, a Tukey's HSD multiple comparison test was conducted.

\section{RESULTS}

\section{Inducible morphological changes}

All of the prey organisms used to prepare the treatment waters were consumed by the crabs. Addition of 
the algal mixture feed gave an obvious greenishbrown shade to the water. After respective exposure periods, control mussels were found to have cleared the water of algae, while the remaining treatment waters still showed some degree of colouration. Control mussels exhibited filter-feeding activity that began a few minutes after the start of the treatment periods.

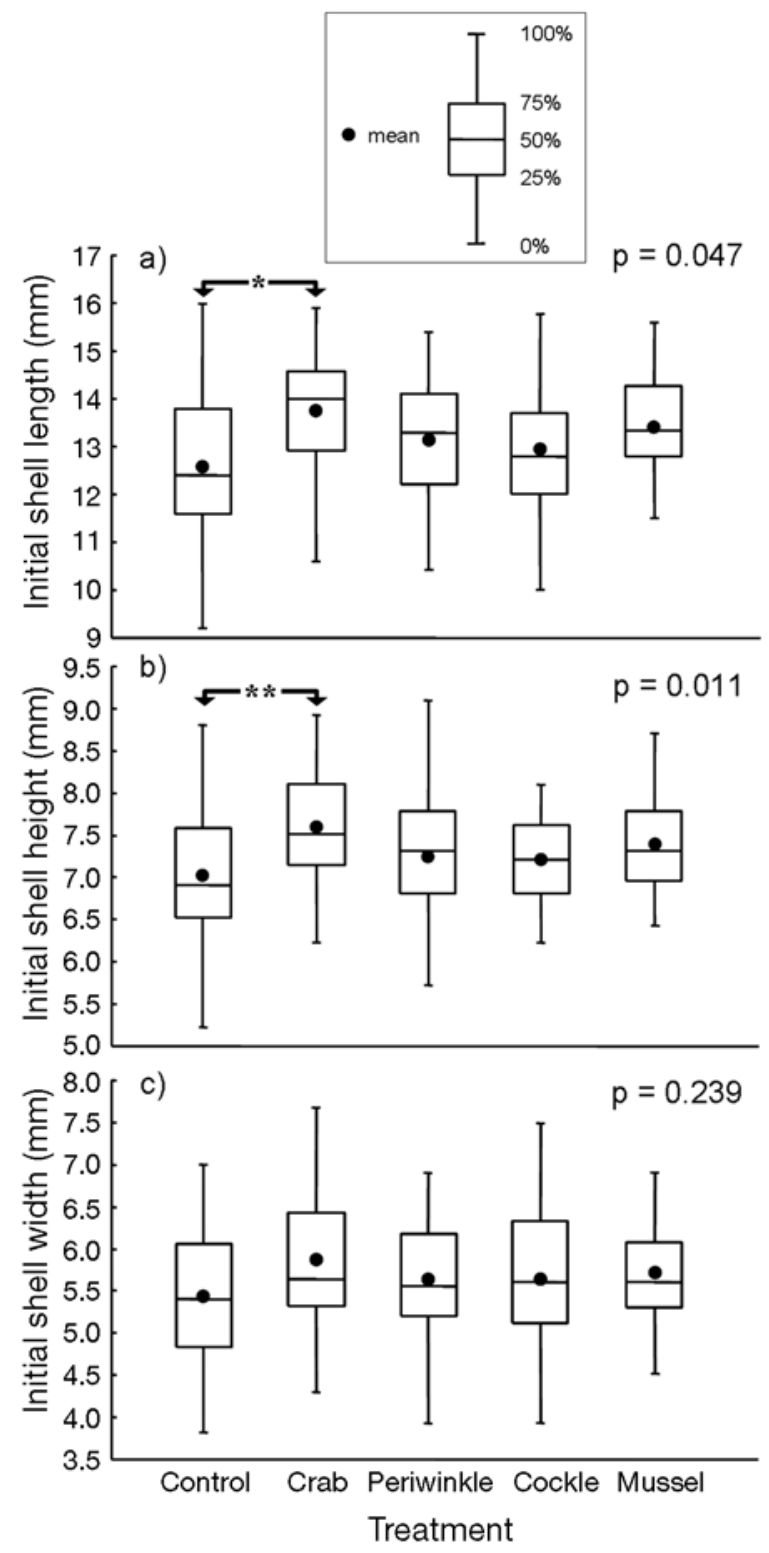

Fig. 1. Mytilus edulis. Differences in initial (a) shell length, (b) shell height and (c) shell width of experimental treatment groups ( $\mathrm{n}=4$ replicates per treatment) before exposure to waterborne cues for $48 \mathrm{~d}$. Control: untreated seawater from the Menai Strait; Crab: unfed crabs; Periwinkle: crabs feeding on Littorina littorea; Cockle: crabs feeding on Cerastoderma edule; Mussel: crabs feeding on Mytilus edulis. Probability value for treatment effect is given; arrows represent statistical significant differences: ${ }^{*} \mathrm{p}<0.05 ;{ }^{* *} \mathrm{p}<0.01$
Mussels exposed to the treatment waters in contrast required a longer period before they started to open their valves, and did so to a lesser extent. Ambient water temperature decreased steadily from 15.2 to $7.9^{\circ} \mathrm{C}$ from the start to the end of the experimental period. Only one mussel died during the experiment.

Initial shell length and initial shell height differed between Mytilus edulis used in the different experimental treatment groups $\left(\mathrm{ANOVA}_{i} F_{4,15}=3.13, \mathrm{p}=\right.$ 0.047 and $F_{4,15}=4.72, \mathrm{p}=0.011$, respectively) (Fig. 1a,b); however, initial shell width did not (ANOVA $F_{4,15}=1.55, \mathrm{p}=0.239$ ) (Fig. 1c). There were no within treatment differences for all initial shell dimensions (ANOVA; shell length: $F_{15,180}=1.60, \mathrm{p}=$ 0.079; shell height: $F_{15,180}=0.92, \mathrm{p}=0.547$; shell width: $\left.F_{15,180}=1.23, \mathrm{p}=0.254\right)$. Mussel growth rates are size dependent and smaller individuals usually experience disproportionately higher growth rates than larger mussels (Seed 1969). Nevertheless, there were no significant relationships between initial and final size among treatments for all shell dimensions analysed (ANCOVA; shell length: $F_{4,186}=0.58, \mathrm{p}=0.678$; shell height: $F_{4,186}=1.05, \mathrm{p}=0.385$; shell width: $F_{4,186}=2.35$, $\mathrm{p}=0.056$ ). Increments in shell dimensions were therefore compared between treatments.

Significant differences were observed for increments in shell dimensions between treatments (ANOVA; shell length: $F_{4,15}=44.37, \mathrm{p}<0.001$; shell height: $F_{4,15}=$ 32.59, p < 0.001; shell width: $F_{4,15}=42.57, \mathrm{p}<0.001$ ) (Fig. 2). Mussels reared for $48 \mathrm{~d}$ in the presence of effluents from predatory crabs feeding on conspecific mussels and cockles increased significantly less in shell dimensions than mussels from the other treatments. The crab treatment yielded increases in shell dimensions which were not significantly different from those of mussels from the periwinkle treatment. Mussels exposed to the control treatment showed the largest increase in shell length over the experimental period and differed significantly from all other treatments (Fig. 2a). Analysis of increases in shell height revealed 2 groups of treatments with similar growth rates which differed significantly from each other (Fig. 2b). There was an overall declining pattern in shell dimension growth from control mussels to conspecific exposed mussels, with those exposed to progressively further related molluscs, i.e. cockles and periwinkles, showing intermediate shell growth responses (Fig. 2).

Dry tissue weight was significantly different between (ANOVA $; F_{4,15}=3.17, \mathrm{p}=0.045$ ) but not within treatments $\left(F_{15,180}=0.94, \mathrm{p}=0.517\right)$ at the start of the experiment. As for size-related growth rates, mussel soft tissue growth may be influenced by initial weight (Seed 1969). However, no relationship could be found between initial dry tissue weight and final dry tissue 
a)

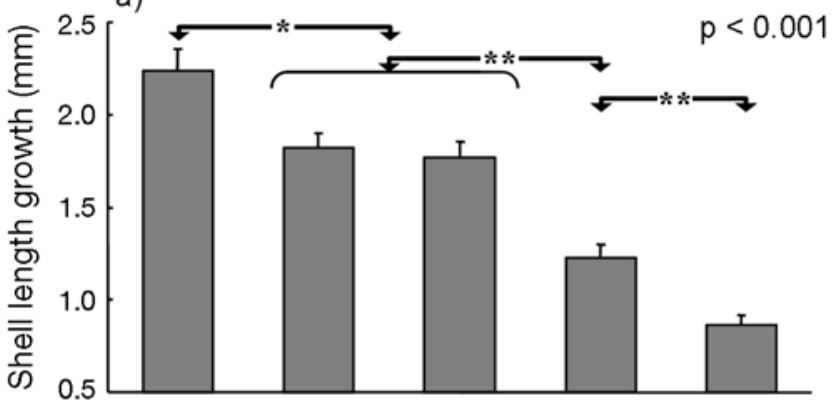

b)

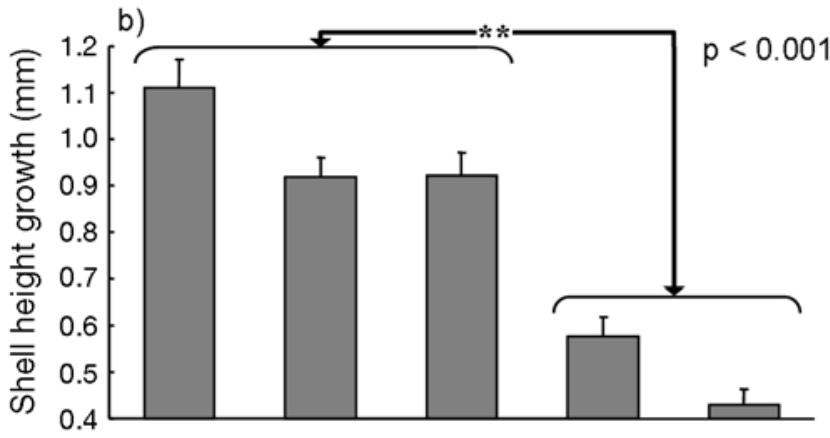

c)

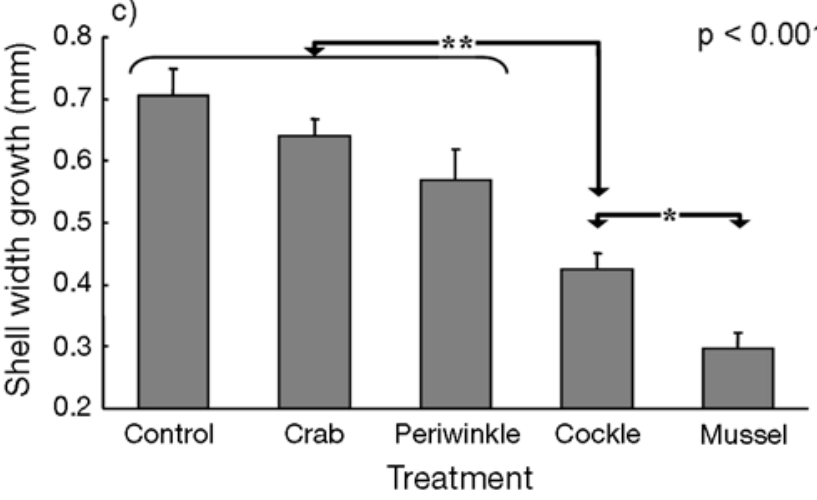

Fig. 2. Mytilus edulis. Growth of (a) shell length, (b) shell height and (c) shell width after exposure to waterborne cues from 5 treatments for 48 d. Treatments are as defined in Fig. 1. Data represent means $\pm \mathrm{SE}(\mathrm{n}=4$ replicates per treatment). Probability value for treatment effect is given; arrows represent statistical significant differences: ${ }^{*} \mathrm{p}<0.05 ;{ }^{* *} \mathrm{p}<0.01$. Round brackets above bars indicate no significant differences between respective treatments

weight among the 5 treatments $\left(\mathrm{ANCOVA}_{i} F_{4,186}=\right.$ 1.03, $\mathrm{p}=0.393$ ). Significant differences were found between treatments for increase in dry tissue weight (ANOVA $F_{4,15}=27.99, \mathrm{p}<0.001$ ) (Fig. 3). Control mussels showed the greatest increase in dry tissue weight compared to mussels exposed to the other 4 treatments. The increase in dry tissue weight in cockle- and conspecific-exposed mussels was significantly less than that of mussels in the other treatments (Fig. 3). Neither of the treatments revealed a final posterior adductor muscle proportion of total tissue dry weight

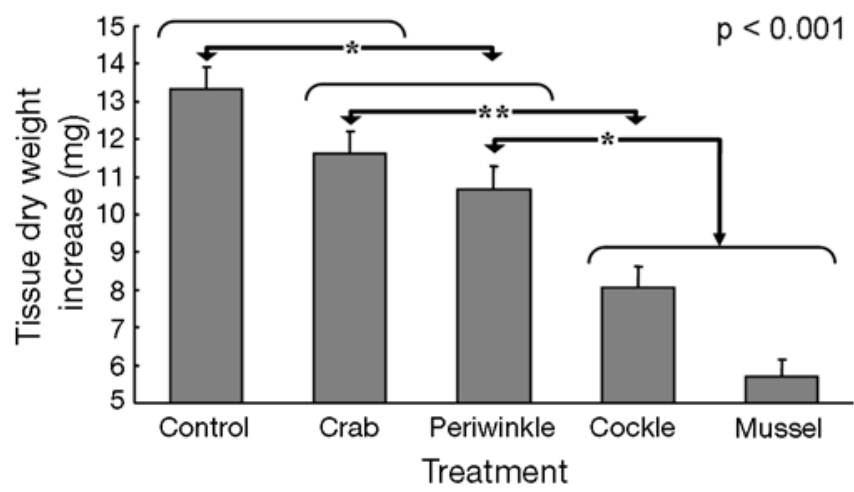

Fig. 3. Mytilus edulis. Increase in tissue dry weight after exposure to waterborne cues from 5 treatments for $48 \mathrm{~d}$. Treatments are as defined in Fig. 1. Data represent means \pm SE ( $n=$ 4 replicates per treatment). Probability value for treatment effect is given; arrows represent statistical significant differences: ${ }^{*} \mathrm{p}<0.05 ;{ }^{* *} \mathrm{p}<0.01$. Round brackets above bars indicate no significant differences between respective treatments

that was significantly different from any of the other treatments $\left(F_{4,15}=0.33, \mathrm{p}=0.854\right)$. Moreover, there were highly significant within treatment differences $\left(F_{15,178}=7.31, \mathrm{p}<0.001\right)$ for muscle dry weight proportions.

Compared to increases in shell dimensions and tissue dry weights, analyses of shell thickness indices among the different treatments revealed a converse result. At the start of the experiment, the shell thickness index for a given length did not differ between or within treatments $\left(\right.$ ANOVA $_{i} F_{4,15}=0.36, \mathrm{p}=0.831$ and $F_{15,180}=1.35, \mathrm{p}=0.178$, respectively). However, significant treatment effects for shell thickness index were evident after experimental exposure to different treatments $\left(F_{4,15}=3.62, p=0.029\right)$ (Fig. 4). Final shell thickness index for a given length was largest for the 2 treatments with cockle and conspecific effluents, which revealed significantly larger shell thickness indices compared to the control. Mussels exposed to effluents of unfed crabs and periwinkles did not differ from unexposed control mussels or mussels exposed to either conspecifics or cockles (Fig. 4).

\section{Byssus thread production}

There were significant differences in the number of byssus threads produced by mussels exposed to the different treatment waters for $6 \mathrm{~h}$ (Kruskal-Wallis test; $H=10.84, \mathrm{df}=4, \mathrm{p}=0.028$ ) (Fig. 5). Multiple comparison of treatment medians indicated that mussels exposed to conspecifics produced significantly more byssus threads compared to control mussels (Dunn's procedure; $\mathrm{p}<0.050$ ). All other treatments showed 


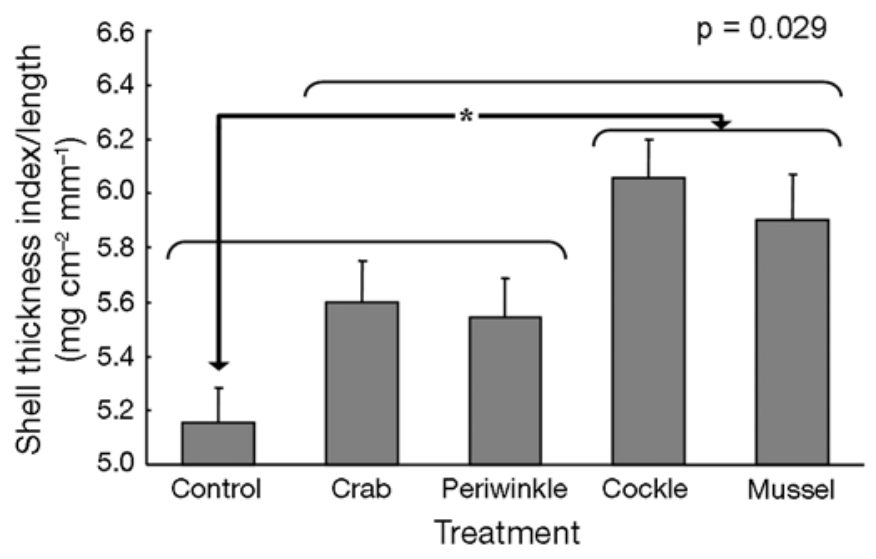

Fig. 4. Mytilus edulis. Differences in shell morphology after exposure to waterborne cues from 5 treatments for $48 \mathrm{~d}$. Treatments are as defined in Fig. 1. Data represent means \pm $\mathrm{SE}(\mathrm{n}=4$ replicates per treatment). Probability value for treatment effect is given; arrows represent statistical significant differences: ${ }^{*} p<0.05$. Round brackets above bars indicate no significant differences between respective treatments

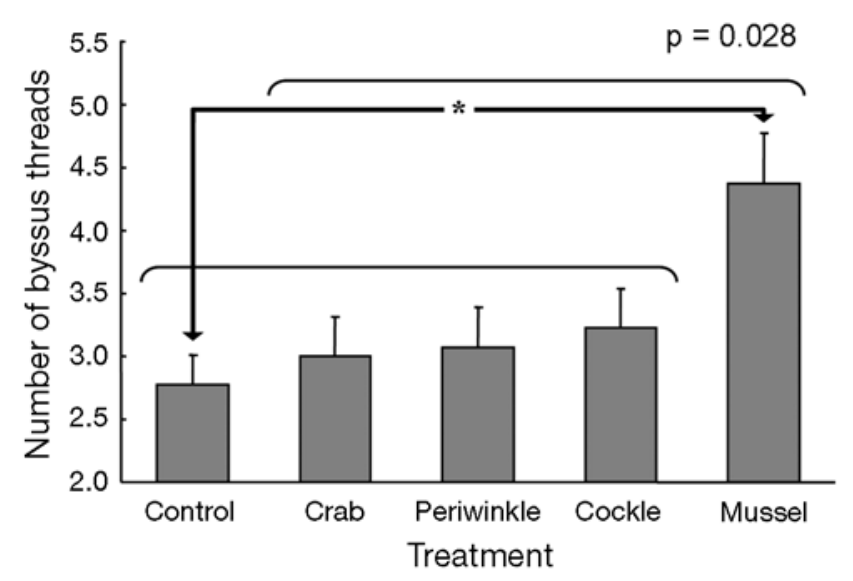

Fig. 5. Mytilus edulis. Byssus thread production after exposure to waterborne cues from 5 treatments for $6 \mathrm{~h}$. Treatments are as defined in Fig. 1. Data represent means \pm SE ( $n=4$ replicate units per treatment). Probability value for treatment effect is given; arrows represent statistical significant differences: ${ }^{*} p<0.05$. Round brackets above bars indicate no significant differences between respective treatments

intermediate responses, which did not differ significantly from either those of the control or the conspecific treatment (Fig. 5). The number of byssus threads produced was highly variable for all treatments (control: $0-5$; crab: 0-9; periwinkle: $0-8$; cockle: $0-8$; mussel: 0-10). A graded series, such as the one observed for responses in morphological changes of experimental mussels, was not observed for responses in byssus thread production. While mussels exposed to conspecific effluents seemed to undergo a similar magnitude of changes in morphological properties compared to cockle-exposed mussels, these 2 treatments showed different trends in production of byssus threads.

\section{DISCUSSION}

Exposure to cues released by crabs feeding on 2 heterospecific molluscs and conspecifics resulted in a graded series of morphological defences in mussels, which became stronger with increasing level of phylogenetic relatedness to the prey organisms. Generally, mussels exposed to cues of predators and damaged molluscs revealed less growth in shell dimensions and soft tissue weight compared to control mussels. On the other hand, shell thickness index was increased in exposed mussels. The nature of the respective response types observed is in agreement with previous investigators; reduced growth in mussel shell dimensions accompanied by increased shell thickening in response to effluents of predators feeding on conspecifics has been demonstrated in Mytilus edulis exposed to waterborne cues of crabs Carcinus maenas (Reimer \& Harms-Ringdahl 2001) and starfish Asterias rubens (Reimer \& Tedengren 1996, Reimer \& HarmsRingdahl 2001). Conversely, in their laboratory experiments, both Leonard et al. (1999) and Smith \& Jennings (2000) did not observe any differences in shell length growth between control mussels and mussels exposed to effluents of dogwhelks Nucella lapillus and crabs feeding on conspecifics. Still, both investigators observed significant increases in shell thickness in predator-exposed mussels. However, it has to be noted that Leonard et al. (1999) had limited replication $(\mathrm{n}=2)$, which resulted in low statistical power. Furthermore, the laboratory experiment of Smith \& Jennings (2000) might have been too short to detect significant differences between the trends in shell dimensions they observed. Field-based experiments generally yielded quicker responses (Reimer \& Tedengren 1996, Reimer \& Harms-Ringdahl 2001). It seems that differences in growth rates may only become evident after a certain minimum period of exposure to respective cues. Feeding of experimental mussels in the present study might have provided comparable field growth conditions for the laboratory-based set up, explaining the differences in growth rates found between treatments after a relatively short exposure time. Nonetheless, there are differences in experimental design, measurement techniques and statistical analysis between the present and previous similar studies, which may have contributed to the differences in outcomes observed. Byssus thread production was enhanced in mussels exposed to effluents from crabs feeding on conspecifics and similar results have been demon- 
strated in earlier studies (Côté 1995, Leonard et al. 1999, Reimer \& Harms-Ringdahl 2001). Based on the results of this study, production of byssus threads might not be a priority means of defensive response, since it seemed to be caused solely by exposure to conspecific cues. Nonetheless, it is unclear why crab cues (from unfed crabs or combined with heterospecifics) did not have a larger effect on byssus thread production, as earlier publications (Côté 1995, Leonard et al. 1999, Reimer \& Harms-Ringdahl 2001) clearly showed the opposite to be true. The variability observed for byssus production in all treatments suggests that longer exposure periods might have revealed clearer differences in this experiment. Despite this, our primary interest was in the difference elicited by different sources of stimuli and whether the magnitude of these differences was linked to phylogenetic relatedness.

Although effects of a variety of different predators on morphological defence induction in Mytilus edulis have been reported (Côté 1995, Reimer \& Tedengren 1996, Leonard et al. 1999, Reimer \& Harms-Ringdahl 2001), the results of this study are the first demonstration of defence responses of mussels exposed to cues of heterospecific molluscs. Griffiths \& Richardson (2006) performed experiments with burrowing bivalves applying a similar concept. They exposed Baltic tellin Macoma balthica to a variety of chemical cues including those of non-feeding crabs Carcinus maenas, crabs feeding on conspecifics, and crabs feeding on a more distantly related bivalve, the cockle Cerastoderma edule. As expected, M. balthica burrowed deeper in the sediment (as an escape response) in the presence of crab effluents. However, the greatest effect was caused by crabs feeding on conspecific bivalves, closely followed by crabs feeding on cockles. The observed graded series of morphological responses in $M$. edulis as a reaction to cues of related species strongly agree with Griffiths \& Richardson (2006). The results from the present study suggest that more closely related molluscs may release similar alarm cues as those released by conspecifics, and therefore may also be able to induce defensive responses in mussels. Exposure to cues of more distantly related mollusc species (periwinkles), however, did not yield results which differed from those of the unfed crab treatment. It is therefore not clear whether the mussels were at all able to pick up cues from the periwinkle. Consequently, a certain level of taxonomic relatedness might exist, above which organisms show an appropriate reaction to alarm cues with a similar chemical signature. Since $M$. edulis seems to show anti-predator responses when exposed to cues of another bivalve $(C$. edule, which belongs to a different taxonomic subclass), this threshold level of taxonomic relatedness may be quite low and generally include various sub- classes of bivalve molluscs. Other species that revealed anti-predator responses when exposed to cues of nonpredatory heterospecifics include fishes (Mirza \& Chivers 2003), crustaceans (Hazlett \& McLay 2005) and heterodont bivalves (Griffiths \& Richardson 2006). These taxa generally showed strong responses to conspecific cues. Heterospecific cues, on the other hand, induced defensive responses which became weaker with decreasing degree of relatedness, indicating an ability of the organisms to differentiate between related species. The results of the present study may suggest that for $M$. edulis there is generally a priority of phylogeny in determining the cues to which the potential prey species will respond. Specific chemical alarm cues may be contained within various Bivalvia subclasses and be instinctively recognisable between related species. Moreover, these alarm cues may either be similar to those released by damaged conspecifics, or they may be identical and accompanied by other chemicals revealing their heterospecific origin. Nevertheless, the lack of consistency among response levels made interpretation difficult. Further work is needed to investigate the maximum level of relatedness to the cue source that is required to trigger defensive responses in the mussel. This may be achieved by exposing mussels to effluents from a wider range of other bivalves or more distantly related molluscs. Additionally, if different body parts are used as potential cue sources, information about the origin of cues inducing defensive responses might be revealed. Replicating the taxonomic type of prey organisms, i.e. by using at least 2 treatments with the same prey organisms, may ease the interpretation of the experimental outcome.

Induction of specific anti-predator attributes in response to effluents released by predators has clear implications for evolutionary fitness. The common response of mussels against crab predators is an increase in shell thickness (Smith \& Jennings 2000, Reimer \& Harms-Ringdahl 2001) and byssus production (Côté 1995, Leonard et al. 1999, Reimer \& HarmsRingdahl 2001). As a consequence, the resistance to breakage and dislodgement by crabs is enhanced. Leonard et al. (1999) showed that mussels, which were exposed to crab effluents, required significantly greater forces to be crushed by crabs compared to control mussels. Moreover, increased attachment strength decreases the probability of successful dislodgement by crabs (Hughes \& Seed 1995). Induction of specific morphological defences increases survival and fitness in mussels by reducing attractiveness to their predators and predator attack success (Reimer \& Tedengren 1996, Smith \& Jennings 2000, Caro \& Castilla 2004). The ability of Mytilus edulis to develop defences when they are needed rather than those being permanently 
expressed, i.e. exhibit phenotypic plasticity, is advantageous from an energetic point of view. As mussels face highly unpredictable and dynamic predation (Beadman et al. 2003), induction of permanent morphological defences would attract fitness costs which could be avoided when predators are absent (Tollrian \& Harvell 1999). Potential trade-offs between shell thickness and size might be involved in predatorinduced defences (Smith \& Jennings 2000) and the advantage of increased shell thickness has to be balanced with the benefit of rapid shell growth (Smith \& Jennings 2000). Ultimately, limited shell growth will restrict increases in soft tissue growth (Palmer 1981) and might lead to a smaller size, which results in reduced gonad production and smaller reproductive output (Smith \& Jennings 2000).

The presence of predators can depress prey foraging behaviour (Appleton \& Palmer 1988), and mussels in particular were found to lower their filter-feeding activity (Reimer et al. 1995) and increase their heart rate (Rovero et al. 1999) when exposed to chemical stimuli of predators. Such impacts will affect metabolic rate, energy acquisition and the growth of prey organisms. Observed behaviour of decreased duration and extent of shell opening in treatment-exposed mussels, coupled with their reduced growth in shell dimensions and soft tissue weight, might indicate an effect of alarm cues on mussel ingestion rates in the present study. If that was the case, morphological changes might have been induced indirectly by defensive behaviour. Shell growth rates in both gastropods and bivalves have been found to be inversely related with shell thickness (Palmer 1981). Furthermore, shell production continues in bivalves in the absence of feeding (Galtsoff 1934). While treatment-exposed mussels had thicker and heavier shells, this might have been a direct result of reduced feeding time and feeding potential, resulting in lower ingestion rates and diminished but dense shell growth. The results from this study, however, also suggest that reduction in shell and tissue growth may reflect the actual fitness costs of morphological defences, as proposed by Reimer \& Tedengren (1996) and Caro \& Castilla (2004). Enhanced allocation of resources to shell material resulting in a thicker shell might consequently be compensated for by reduced tissue and shell dimension growth. Whether predator-induced changes result from the mussels' ability to react to cues of different predators and apply direct changes to its morphology, or whether such changes are indirectly caused by behaviour patterns linked to predation is still debatable. It is presently not clear if (deliberately) induced shell thickness is the reason for slower growth, or if constrained ingestion and growth rates indirectly cause enhanced shell thickness. The fact that both
Leonard et al. (1999) and Smith \& Jennings (2000) observed unaffected shell growth rates but increased shell thickness in mussels exposed to predatory crab effluents, while control mussels had similar growth rates but thinner shells, is somewhat puzzling. Their findings suggest that both exposed (thick shell inducing) and control (thin-shelled) mussels reach a potential mutual maximum rate of growth (see Palmer 1981). However, given the energetic cost associated with the production of shell material (Palmer 1992), organisms with a thick shell will require more energy to achieve the same growth rates of thin-shelled individuals (Palmer 1981). Unfortunately, information about (enhanced) filter-feeding activity or ingestion rates of alarm cue-exposed mussels was not considered in their investigations. Besides, Smith \& Jennings (2000) found no differences in tissue dry weight between treatments. Carefully planned, long-term experiments, which take into account ingestion rates in combination with tissue allocation, might have some merit in examining energetic requirements of induced defences, their exact source of stimulus and whether they are reversible.

Acknowledgements. The authors thank B. Roberts, G. Hughes, A. B. Yule and L. R. Teal for their various inputs to the research. We declare that the methods in this paper comply with the current laws of the United Kingdom that pertain to experimental procedures using animals.

\section{LITERATURE CITED}

Appleton RD, Palmer AR (1988) Water-borne stimuli released by predatory crabs and damaged prey induce more predator-resistant shells in a marine gastropod. Proc Natl Acad Sci USA 85:4387-4391

Asmus H, Asmus RM (1993) Phytoplankton-mussel bed interactions in intertidal ecosystems. In: Dame RF (ed) Bivalve filter feeders in estuarine and coastal ecosystem processes. Springer-Verlag, Berlin, p 149-196

Beadman HA, Caldow RWG, Kaiser MJ, Willows RI (2003) How to toughen up your mussels: using shell morphological plasticity to reduce predation losses. Mar Biol 142: 487-494

Brown GE, Godin JGJ (1997) Anti-predator responses to conspecific and heterospecific skin extracts by three-spine sticklebacks: alarm pheromones revisited. Behaviour 134: 1123-1134

Caldow RWG, Beadman HA, McGrorty S, Kaiser MJ, GossCustard JD, Mould K, Wilson A (2003) Effects of intertidal mussel cultivation on bird assemblages. Mar Ecol Prog Ser 259:173-183

Caro AU, Castilla JC (2004) Predator-inducible defences and local intra-population variability of the intertidal mussel Semimytilus algosus in central Chile. Mar Ecol Prog Ser 276:115-123

Côté IM (1995) Effects of predatory crab effluent on byssus production in mussels. J Exp Mar Biol Ecol 188:233-241

Côté IM, Jelnikar E (1999) Predator-induced clumping behaviour in mussels (Mytilus edulis Linnaeus). J Exp Mar Biol Ecol 235:201-211 
Dare PJ (1976) Settlement, growth and production of the mussel, Mytilus edulis L., in Morecambe Bay, England. Fish Invest Ser II 28, No. 1, London, p 1-25

Ebling FG, Kitching JA, Muntz L, Taylor CM (1964) The ecology of Lough Ine XIII. Experimental observations of the destruction of Mytilus edulis and Nucella lapillus by crabs. J Anim Ecol 33:73-82

Freeman AS, Byers E (2006) Divergent induced responses to an invasive predator in marine mussel populations. Science 313:831-833

Galtsoff PS (1934) The biochemistry of the invertebrates of the sea. Ecol Monogr 4:481-490

Goss-Custard JD, Durrell SEA (1987) Age-related effects of oystercatchers, Haematopus ostralegus, feeding on mussels, Mytilus edulis. II. Aggregation. J Anim Ecol 56: 537-548

Griffiths CL, Richardson CA (2006) Chemically induced predator avoidance behaviour in the burrowing bivalve Macoma balthica. J Exp Mar Biol Ecol 331:91-98

Grosberg RK (1988) The evolution of allorecognition specificity in clonal invertebrates. Q Rev Biol 63:377-412

Harvell CD (1984) Predator-induced defence in a marine bryozoan. Science 224:1357-1359

Hazlett BA, McLay C (2005) Responses of the crab Heterozius rotundifrons to heterospecific chemical alarm cues: phylogeny vs. ecological overlap. J Chem Ecol 31:671-677

Hickman RW (1992) Mussel cultivation. In: Gosling E (eds) The mussel Mytilus: ecology, physiology, genetics and culture. Elsevier, Amsterdam, p 465-510

Hughes RN, Seed R (1995) Behavioral mechanisms of prey selection in crabs. J Exp Mar Biol Ecol 193:225-238

Leonard GH, Bertness MD, Yund PO (1999) Crab predation, waterborne cues, and inducible defences in the blue mussel, Mytilus edulis. Ecology 80:1-14

Lively CM (1986) Predator-induced shell dimorphism in the acorn barnacle Chthamalus anisopoma. Evolution 40: 232-242

Mathis A, Smith RJF (1993) Intraspecific and cross-superorder responses to chemical alarm signals by brook stickleback. Ecology 74:2395-2404

> Mirza RS, Chivers DP (2003) Influence of body size on the responses of fathead minnows, Pimephales promelas, to damselfly alarm cues. Ethology 109:691-699

Moore PG, Howarth J (1996) Foraging by marine scavengers: effects of relatedness, bait damage and hunger. J Sea Res $36: 267-273$

Norberg J, Tedengren M (1995) Attack behaviour and predatory success of Asterias rubens L. related to differences in

Editorial responsibility: Roger Hughes,

Bangor, UK size and morphology of the prey mussel Mytilus edulis L. J Exp Mar Biol Ecol 186:207-220

Palmer AR (1981) Do carbonate skeletons limit the rate of body growth? Nature 292:150-152

Palmer AR (1992) Calcification in marine molluscs: How costly is it? Proc Natl Acad Sci USA 89:1379-1382

> Reimer O, Harms-Ringdahl S (2001) Predator-inducible changes in blue mussels from the predator-free Baltic Sea. Mar Biol 139:959-965

Reimer O, Tedengren M (1996) Phenotypical improvement of morphological defences in the mussel Mytilus edulis induced by exposure to the predator Asterias rubens. Oikos 75:383-390

Reimer O, Olsson B, Tedengren M (1995) Growth, physiological rates and behaviour of Mytilus edulis exposed to the predator Asterias rubens. Mar Freshw Behav Physiol 25: 233-244

Rovero F, Hughes RN, Chelazzi G (1999) Cardiac and behavioural responses of mussels to risk of predation by dogwhelks. Anim Behav 58:707-714

Seed R (1969) The ecology of Mytilus edulis L. (Lamellibranchiata) on exposed rocky shores. II. Growth and mortality. Oecologia 3:317-350

Seed R (1976) Ecology of marine mussels. In: Bayne BL (ed) Marine mussels: their ecology and physiology. Cambridge University Press, Cambridge, p 13-65

Seed R (1993) Invertebrate predators and their role in structuring coastal and estuarine populations of filter feeding bivalves. In: Dame RF (ed) Bivalve filter feeders in estuarine and coastal ecosystem processes. Springer-Verlag, Berlin, p 149-195

Seed R, Suchanek TH (1992) Population and community ecology of Mytilus. In: Gosling E (ed) The mussel Mytilus: ecology, physiology, genetics and culture. Elsevier, Amsterdam, p 87-157

Smith LD, Jennings JA (2000) Induced defensive responses by the bivalve Mytilus edulis to predators with different attack modes. Mar Biol 136:461-469

Tollrian R, Harvell CD (1999) The ecology and evolution of inducible defences. Princeton University Press, Princeton, NJ

Wicklow BJ (1988) Developmental polymorphism induced by intraspecific predation in the ciliated protozoan Onychodromus quadricornutus. J Protozool 35:137-141

Wisenden BD, Chivers DP, Brown GE, Smith RJF (1995) The role of experience in risk assessment: avoidance of areas chemically labelled with fathead minnow alarm pheromone by conspecifics and heterospecifics. Ecoscience 2:116-122

Submitted: October 25, 2007; Accepted: February 25, 2008 Proofs received from author(s): June 23, 2008 